

\section{DISCLAIMER}

This report was prepared as an account of work sponsored by an agency of the United States Government. Neither the United States Government nor any agency Thereof, nor any of their employees, makes any warranty, express or implied, or assumes any legal liability or responsibility for the accuracy, completeness, or usefulness of any information, apparatus, product, or process disclosed, or represents that its use would not infringe privately owned rights. Reference herein to any specific commercial product, process, or service by trade name, trademark, manufacturer, or otherwise does not necessarily constitute or imply its endorsement, recommendation, or favoring by the United States Government or any agency thereof. The views and opinions of authors expressed herein do not necessarily state or reflect those of the United States Government or any agency thereof. 


\section{DISCLAIMER}

Portions of this document may be illegible in electronic image products. Images are produced from the best available original document. 
This book was proasred as an account of work sponsored by an agency of the United States Government. Neither tha United Strtes Government nor any agency thereof, nor any of their employees, makes any werranty, express or Implied. Of assumes any logal lisbility or responsibility for the eccuracy.

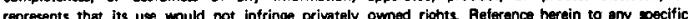

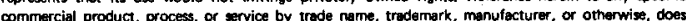
not necessarily constitute or imply its endorsement. recommendation, or favoring by the United States Government of any egency thereot. The views and opinions of wuthors expressed herein do not necesserily state or reflict those of the United States Government or any agency thereof.

\title{
GEOTHERMAL UTILIZATION AT CASTLE OAKS SUBDIVISION, CASTLE ROCK, COLORADO
}

\author{
Kenneth L. Garing \\ Glenn E. Coury \\ Steven W. Goering
}

Published April 1982

Coury and Associates, Inc. Lakewood, Colorado 80226

Prepared for EG\&G Idaho, Inc.

Under Subcontract No. K-7835

and the U.S. Department of Energy

Idaho Operations Office

Under DOE Contract No. DE-AC07-76ID01570

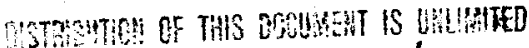




\section{ABSTRACT}

Designs of geothermal systems for using warm water from four aquifers of the Denver Basin are presented. Advantages of using heat pumps with the geothermal resource are discussed. Two design cases-one with separate heat load and heat pump, and the other with the heat pump and heat load located at the well site-are evaluated in terms of pump costs, operating costs, and payback periods. The 20 -year delivered energy costs for the two geothermal systems would be slightly less than those for natural gas ( $\$ 5.64$ to $\$ 6.42$ versus $\$ 6.70$ per million Btu). 


\section{FOREWORD}

The Geothermal Technical Assistance Program was developed under the premise that the majority of groups or individuals with available geothermal resources do not have the experience or manpower necessary to do a preliminary engineering and economic feasibility evaluation for geothermal energy projects. In order to disseminate technical information and to facilitate expanded use of geothermal energy resources, assistance was provided through FY-1981 in a consulting format on a first-come, staff-andfunds-available basis. Technical assistance can relate to conceptualization; engineering; economics; water chemistry implications for environmental, disposal, and material selection considerations; and planning and development strategies. This report is one of a series adapted from consultation provided to requesters either through in-house efforts or through limited efforts subcontracted to local engineering firms. The Geothermal Technical Assistance (GTA) Reports in this series, which are listed below, will be available for purchase early in 1982 by those with interest in specific geothermal applications from the U.S. National Technical Information Service:

U.S. Department of Commerce,

National Technical Information Service, 5285 Port Royal Road, Springfield, VA 22161, (703) $557-4650$

GTA

Report Number

1.

2.

3.

4.

5.

6.

7.

EGG-GTH-5617

8.

9.
EG\&G

Report Number

*EGG-GTH-5512

*EGG-GTH-5521

*EGG-GTH-5573

*EGG-GTH-5574

*EGG-GTH-5575

*EGG-GTH-5599
*EGG-2137

*EGG-2138
Title

Aquaculture Facility Potential at Boulder Hot Springs, Boulder, Montana

Preliminary Geothermal Disposal Considerations, State Health Laboratory, Boise, Idaho

Geothermal Conversion at Veterans Hospital, Boise, Idaho

Geothermal Applications for Highway Rest Areas

Geothermal Applications for a Tannery

Preliminary Conceptual Design for Geothermal Space Heating Conversion of School District 50 Joint Facilities at Pagosa Springs, Colorado

Selected Geothermal Technical Assistance Efforts (comprising short descriptions of ten space heating projects, five district heating projects, and three heat exchanger projects)

Geothermal Source Potential and Utilization for Methane Generation and Alcohol Production (subcontractor report)

Geothermal Source Potential and Utilization for Alcohol Production (subcontractor report) 
GTA

Report Number

10.

*EGG-2139

11.

EGG-2144

12.

*EGG-2145

13.

*EGG-2146

14.

*EGG-2147

15.

*EGG-2148

16.

EGG-2149

17.

18.

19.

20.

21.

22.

23.

*EGG-2156

25.
EG\&G

Report Number

Title

Potential Geothermal Energy Applications for Idaho Elks Rehabilitation Hospital (subcontractor report)

Technical Assistance Report on a Geothermal Heating Utility for Lemmon, South Dakota (subcontractor report)

Economic Analysis for Utilization of Geothermal Energy by North Dakota Concrete Products Company (subcontractor report)

Geothermal Feasibility Analysis II for Polo School District No. 29-2, South Dakota (subcontractor report)

Preliminary Feasibility Study of Heating and Cooling Alternatives for Nebraska Western College, Scottsbluff, Nebraska (subcontractor report)

Inventory of Thermal Springs and Wells Within a OneMile Radius of Yucca Lodge, Truth or Consequences, New Mexico (subcontractor report)

Utilization of Geothermal Energy, Feasibility Study-Ojo Caliente Mineral Springs Company, Ojo Caliente, New Mexico (subcontractor report)

Geothermal Heated Office Building at Glenwood Springs, Colorado (subcontractor report)

Final Report-Dickinson Geothermal Study, Dickinson, North Dakota (subcontractor report)

\section{CANCELLED}

Comparison of Two Options for Supplying Geothermal Energy to the Veterans Administration Medical Center, Marlin, Texas (subcontractor report)

Geothermal Utilization at Castle Oaks Subdivision Castle Rock, Colorado (subcontractor report)

Space Heating for Twin Lakes School Near Gallup, New Mexico (subcontractor report)

Pumping Tests of Well Campbell et al. No. 2, Gila Hot Springs, Grant County, New Mexico (subcontractor report)

Geothermal Deicing of Highways and Bridge structures

Assessment of a Geothermal Application at Tucson, Arizona 
GTA

Report Number

26.

27.

28.

29.
EG\&G

Report Number

*EGG-GTH-5741

EGG-GTH-5779

EGG-GTH-5804
Title

Heat Pump Systems for Spring Creek, Montana

Pipe Selection Guide

An Overview of Engineering and Agricultural Design Considerations of the Raft River Soil-Warming and Heat-Dissipation Experiment

Design of the Glenwood Springs Downhole Heat Exchanger

*Published as of 4/1/82. 


\section{PREFACE}

This report was prepared for EG\&G Idaho by Coury and Associates, Inc., on Subcontract No. K-7835 under the Department of Energy's Outreach Program. It is now being reissued without modification as an EG\&G formal report in order to make it available to others that may be interested in this geothermal application. 


\section{TECHNICAL ASSISTANCE REPORT \\ GEOTHERMAL UTILIZATION AT CASTLE OAKS SUBDIVISION, CASTLE ROCK, COLORADO \\ Final Report}

Kenneth L. Garing

GTenn E. Coury

Steven W. Goering

March 1982

Coury and Associates, Inc.

Lakewood, Colorado 80226

Prepared for Park Funding Corporation

Under Subcontract No. K-7835

Wi th EG\&G Idaho, Inc. 


\section{CONTENTS}

Page

Introduction................................ 1

I. Resource Assessment...................... 2

II. Geothermal Utilization................... 4

Direct-Use Possibilities................... 4

Heat Pump Application..................... 6

Heat Pump Cycle........................ 7

Sys tem Layout........................ 10

Pump................................. 11

Design............................. 11

III. Economic Considerations.................. 16

Capital Costs........................... 16

Operating Costs...................... 17

Annual Fuel Displaced.................. 18

Payback.............................. 18

Tax Incentives for Geothermal Development...... 21

Federal Energy Tax Credit................. 22

Intangible Drilling Cost Deductions........... 23

Depletion Allowance....................... 25

Colorado Energy Tax Credit................ 26

Summary................................. 27

Bibliography............................ 28 


\section{FIGURES}

Page

1. Schematic Diagram of Heat Pump Operation........ 8

2. Schematic Diagram of Flow of Geothermal Fluid..... 13

3. Schematic of Solar Assisted Geothermal Heat Pump... 14

\section{TABLES}

1. Expected Flow Rates and Other Resource Data....... 2

2. Appropriated Water Rights for 3700-Acre Development.............................. 2

3. Heat Pump Characteristics.................. 9

4. Pressure Loss per 1000 Feet of a Concrete Asbes tos Product........................... 11

5. Temperature Loss in ${ }^{\circ} \mathrm{F}$ per 1000 Feet of Concrete Pipe.............................. 11

6. Design Heat Loads for Average Buildings......... 12

7. Total Capital Costs.......................... 17

8. Simple Payback Calculation................. 18

9. 20-Year Energy Costs....................... 19

10. Comparative 20-Year Energy Costs--Zero Inflation Rates................................... 20 


\section{INTRODUCTION}

Park Funding Corporation is in the preliminary design stages for a major new 3,700-acre housing development located approximately 30 miles south of Denver near the community of Castle Rock, Colorado. The development will eventually provide homes for between 50,000 and 60,000 people. In addition to single- and multifamily residential sites, areas will be provided for schools, medical centers, commercial development, and limited light industrial facilities.

Water for the development will come from the four distinct aquifers of the Denver Basin geological formation. Production wells have been drilled to each of the four aquifers; water temperatures range from $65^{\circ} \mathrm{F}$ to $105^{\circ} \mathrm{F}$. Coury and Associates, Inc. is the contractor for Park Funding Corporation through the Department of Energy's Technical Assistance Program to provide assistance for the design of geothermal systems utilizing the warm water supplied from the wells.

This report summarizes the results of those activities. The report is divided into three sections entitled Resource Assessment, Geothermal Utilization, and Economic Considerations. In the first section, Resource Assessment, the resource is appraised. In the second section, Geothermal Utilization, the direct-use possibilities of the geothermal resource and heat pump applications are discussed. Also in this section, the preferred approach for geothermal utilization is outlined and heat loads are estimated. In the last section, Economic Considerations, the capital costs, operating costs, payback periods, and tax incentives are detailed. 


\section{RESOURCE ASSESSMENT}

Water for this development is provided from the Denver Basin. This water source is composed of four distinct water aquifers, the Dawson, the Denver, the Arapahoe, and the Fox Hills. Presently, two wells are completed into each of the four aquifers. At full development, 14 wells will tap into each of the aquifers. The expected production flow rates of wells from each of the aquifers along with other resource data are presented in Table 1.

TABLE 1. EXPECTED FLOW RATES AND OTHER RESOURCE DATA

\begin{tabular}{|c|c|c|c|c|}
\hline Aquifer & $\begin{array}{l}\text { Depth to } \\
\text { Formation } \\
\text { (ft) }\end{array}$ & $\begin{array}{c}\text { Static Water } \\
\text { Level Below } \\
\text { Surface } \\
(\mathrm{ft}) \\
\end{array}$ & $\begin{array}{c}\text { Expected } \\
\text { Flow per } \\
\text { Wel1 } \\
\text { (gpm) } \\
\end{array}$ & $\begin{array}{c}\text { Expected } \\
\text { Temperature } \\
\text { (OF) }\end{array}$ \\
\hline $\begin{array}{l}\text { Dawson } \\
\text { Denver } \\
\text { Arapahoe } \\
\text { Fox Hills }\end{array}$ & $\begin{array}{l}1000 \\
1500 \\
2300 \\
2800\end{array}$ & $\begin{array}{r}400 \\
600 \\
800 \\
1000\end{array}$ & $\begin{array}{l}200 \\
150 \\
300 \\
150\end{array}$ & $\begin{array}{r}65 \\
80 \\
90 \\
105\end{array}$ \\
\hline
\end{tabular}

The water to be withdrawn from these wells has been appropriated by permit from the State Engineer for use as the water supply for the development. Table 2 presents the amount of the water appropriation.

TABLE 2. APPROPRIATED WATER RIGHTS

FOR 3700-ACRE DEVELOPMENT

\begin{tabular}{|c|c|c|}
\hline Aquifer & $\begin{array}{c}\text { Appropriated } \\
\text { Water } \\
\text { (million gal/yr) }\end{array}$ & Acre $\mathrm{ft} /$ acre \\
\hline $\begin{array}{l}\text { Dawson } \\
\text { Denver } \\
\text { Arapahoe } \\
\text { Fox Hills }\end{array}$ & $\begin{array}{l}543 \\
157 \\
543 \\
289\end{array}$ & $\begin{array}{l}0.45 \\
0.13 \\
0.45 \\
0.24\end{array}$ \\
\hline
\end{tabular}


The values presented above are the maximum permitted quantities of water which may be withdrawn from the indicated aquifer on an annual basis. The water may be withdrawn at any time during the year and at any pumpage rate as long as the appropriation is not exceeded.

The quality of the water is expected to be good. Available water samples indicate the water nearly meets drinking water standards. No treatment for scaling or corrosion is anticipated at this time. 


\section{GEOTHERMAL UTILIZATION}

This section outlines potential ways for utilizing the geothermal resource. Direct-use possibilities are discussed first and are followed by specific discussions of heat pump use based on the available resource temperatures. Several system designs are then presented at the end of this section.

\section{DIRECT-USE POSSIBILITIES}

Radiant heating is an alternative to hot water convection heating and is more applicable for use in the $100^{\circ} \mathrm{F}$ temperature range. In this heating mode, heat is transferred by radiation from a warm or hot surface to objects and other surfaces. For space heating, this may be accomplished by embedding heating coils in floors, walls, or ceilings. The simplest and cheapest of these alternatives is to embed coils in floors, specificaliy plastic pipe in concrete floors. Such a system, also known as slab heating, needs to be installed during construction. The floor itself becomes the radiating surface, and the heat flux can be controlled by controlling its surface temperature; this in turn may be controlled either by the flow of fluid through the coils, design of the spacing of the coils, or both. The typical floor surface temperature for living comfort is $85^{\circ} \mathrm{F}$. Fluid temperature of $100^{\circ} \mathrm{F}$ is considered the lower temperature limit since that is the minimum temperature which can practically be used to give an $85^{\circ} \mathrm{F}$ floor temperature for floors without floor coverings. At lower fluid temperatures, the need for closely spaced coils and thus for more coil area or for higher flow rates results in increasingly prohibitive costs. Only the geothermal fluid from the Fox Hills formation can be considered for this type of slab heating.

The components needed for this type of slab heating are: coils and piping, controls, pumps, and vents. The controls may be indoor or outdoor thermostats and flow balancing valves. Vents are needed to prevent air from collecting in the highest point of the piping and coil system. With the advent of suitable plastic pipe, the equivalent annual operating and capital costs for radiant floor heating are typically lower than that for baseboard, forced air, radiant ceiling and heat pump al ternatives where 
fluid temperatures are significantly below about $150^{\circ} \mathrm{F}$. Only the heat pump and radiant heating options are viable for temperatures at the $100^{\circ} \mathrm{F}$ level. The limitation on floor radiant heating is the lower fluid operating temperature limit of about $100^{\circ} \mathrm{F}$ as noted above. Heat pumps can operate well below this limit.

slab heating has several comfort and other advantages. Some of these are:

--Temperature differences are small throughout a room and between floor and ceiling.

--There are no drafts or dead-air spaces, as natural convection circulates the air.

--There are no cold surfaces in the room, as the fluid-warmed surfaces heat the other surfaces by radiation.

--There are fewer cleaning or decorating problems due to the hidden nature of the heating system.

Some disadvantages of slab heating are:

--Cooling is not provided for. This may be a factor where cooling in summer is important.

--There is no provision for filtration of dust and pollen for those people with allergies.

--The thermal response time may be too slow for solar-type structures with large glass areas.

--Leaks, though uncommon, are difficult to repair.

--Floor coverings have a considerable effect on heat output and are thus a design factor.

The deicing of, or snow melting from, sidewalks can also be considered a type of slab heating application. In this use, geothermal temperatures as low as $60^{\circ} \mathrm{F}$ can effectively be used. To avoid the possibility of pipe breakage due to freezing, it is recommended that an intermediate heating fluid containing a glycol mixture be used. This, however, necessitates the use of a plate heat exchanger to transfer heat from the geothermal fluid to the intermediate heating fluid. If the geothermal fluid were to be used solely for this deicing purpose, the cost of the heat exchanger would make this approach economically unattractive. However, with cascade use in conjunction with a heat pump application, the economics of deicing are enhanced. 
Another potential direct-use possibility for using the low-temperature geothermal resource is in the preheating of makeup air. Several facilities require, or are mandated by State health regulations to have high air turnover rates. High air turnover rates means that large volumes of outside air are brought inside to change over or replace the existing inside air. Facilities usually having high air turnover requirements include hospitals, medical centers, sports centers, and gymnasiums. The air brought into these facilities must be heated prior to distribution. The preheating of this makeup air is where the geothermal resource could be used. A good example of this type use is at the St. Mary's Hospital in Pierre, South Dakota. The available geothermal resource enters the building at $105^{\circ} \mathrm{F}$ and is lowered to $65^{\circ} \mathrm{F}$ prior to river discharge. The reader is directed to the bibliography for additional information of this particular installation. If these types of facilities can be located near the well sites, this direct-use potential of the resource may be significant.

\section{HEAT PUMP APPLICATION}

Due to the low temperature, the use of the geothermal resource for direct applications is likely limited to snow melting, makeup air preheating, and slab heating as mentioned above. However, with the use of commercially available heat pumps, the usefulness of the geothermal resource can be greatly enhanced. Selected heat pumps can operate effectively on either the $105^{\circ} \mathrm{F}$ or the $90^{\circ} \mathrm{F}$ resource and could provide water at $140^{\circ} \mathrm{F}$, which can then be used for space heating and domestic hot water supplies. In addition to providing warmed waters for heating, the heat pump can be operated in the reverse mode as a water chiller to provide space cooling. When operating as a water chiller, water at $45^{\circ} \mathrm{F}$ can be produced from the heat pump operation.

Specific information has been obtained on heat pumps which can operate on the available $105^{\circ} \mathrm{F}$ or $90^{\circ} \mathrm{F}$ resource for both heating and cooling. Heat pumps can operate with temperatures less than $90^{\circ} \mathrm{F}$; however, the efficiency is usually lowered. Based on the resource evaluation, the heat pump discussed is practical. For different resource temperatures and flow rates, different model heat pumps may be advised. 
Heat Pump Cycle

A11 heat pumps operate on the simple scientific principle that fluid absorbs heat when it evaporates into a gas and gives off heat when it condenses back into a liquid. Heat pump operation is based on this principle using four mechanical components and a chemical refrigerant. The four components are an evaporator, a compressor, a condenser, and an expansion valve. The chemical refrigerant is the key to making a heat pump work. The refrigerant used in most groundwater heat pumps has a boiling point close to $0^{\circ} \mathrm{F}$. To make the heat pump work, electrical energy must be added to operate a compressor.

Figure 1 is a schematic diagram showing heat pump operation during the heating mode. The well water enters and flows through the evaporator portion of the heat pump. The evaporator is a coil heat exchanger in which the vapor-liquid refrigerant mixture absorbs heat from the geothermal fluid and is evaporated to a vapor. From the evaporator, the vapor passes to the compressor where it is compressed to a higher pressure and a higher temperature. Leaving the compressor, the hot vapor passes to the condenser. In the condenser, the refrigerant is cooled to a warm liquid. After passing through the condenser, the pressure of the refrigerant is relieved at the expansion valve. At this point, a cool liquid and vapor mixture is obtained and sent to the evaporator to repeat the whole process. Each of the above operations is performed continuously when the heat pump is operating. 


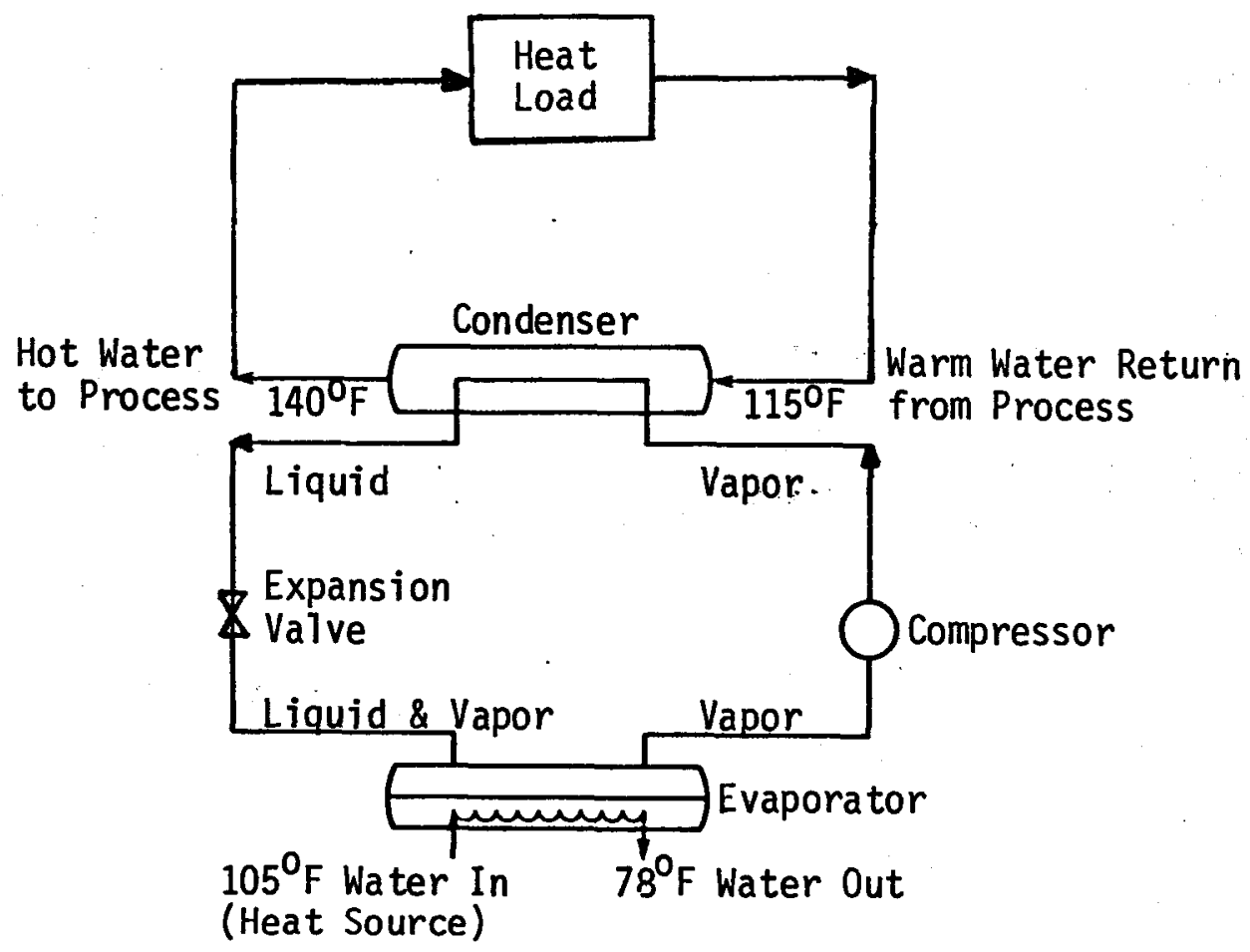

Figure 1. Schematic Diagram of Heat Pump Operation

The efficiency of a heat pump is measured by its coefficient of performance $(C O P)$. The definition of $C O P$ is:

$$
\text { COP }=\frac{\text { energy output from heat pump }}{\text { electrical energy input to heat pump }}
$$

The energy output from a heat pump is dependent on the mode of operation. When heating a building, the COP is based on thermal energy added to the building. In warm months when cooling is required, the COP is based on the thermal energy removed from the building. The COP values for both heating and cooling vary with different input temperatures of the groundwater.

The operating conditions of the one possible heat pump are presented in Table 3. 
TABLE 3. HEAT PUMP CHARACTERISTICS

$90^{\circ} \mathrm{F}$ Resource

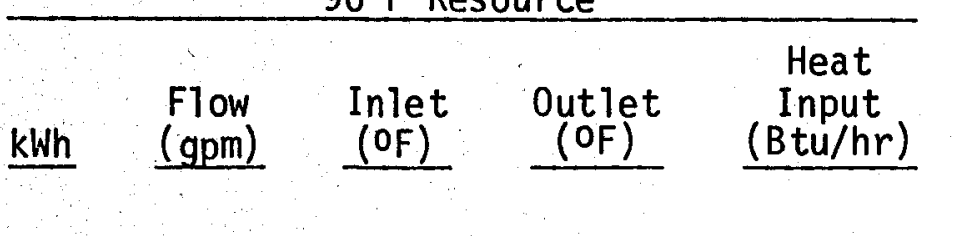

Heating

Evaporator

(geothermal flow)

Condenser

(circulating flow)

Compressor

electrical input

201

Total

COP

EER

Cooling

\section{Evaporator}

(circulating flow)

Condenser

(geothermal flow)

Compressor

electrical input

155

Total

COP

EER

* Expected flow per well from Arapahoe aquifer.

** Expected flow per well from Fox Hills aquifer.

\begin{tabular}{|c|c|c|c|}
\hline $300 *$ & 90 & 74.4 & $2,340,000$ \\
\hline 245 & 115 & 140 & \\
\hline & & & 680,000 \\
\hline & & & $3,020,000$ \\
\hline & & & 4.4 \\
\hline & & & 15.0 \\
\hline
\end{tabular}

$\begin{array}{ccc}300 & 58 & 45 \\ 300 * & 90 & 106.8\end{array}$

\begin{tabular}{|c|c|c|c|c|}
\hline kWh & $\begin{array}{r}\text { Flow } \\
\text { (gpm) }\end{array}$ & $\begin{array}{c}\text { Inlet } \\
\text { (OF) }\end{array}$ & $\begin{array}{l}\text { Outlet } \\
\text { (OF) }\end{array}$ & $\begin{array}{c}\text { Heat } \\
\text { Input } \\
\text { (Btu/hr) }\end{array}$ \\
\hline
\end{tabular}

$150 * * \quad 105 \quad 78 \quad 2,030,000$

$215 \quad 115 \quad 140$

150

58

45

150

105

122

$529,000 \quad 155$
$2,000,000$
(165 tons)

3.8

12.9
529,000

$1,000,000$ (80 tons)

1.9

6.4 


\section{System Layout}

An important consideration in the utilization of the geothermal resource, whether used directly or passed through heat pumps, is the transmission pipeline. For the direct utilization of the resource, the transmission pipeline would carry either $150 \mathrm{gpm}$ of $105^{\circ} \mathrm{F}$ or $300 \mathrm{gpm}$ of $90^{\circ} \mathrm{F}$ fluid from the Fox Hills or Arapahoe aquifers, respectively. If the resource is first passed through a heat pump, the transmission line will carry flows of $215 \mathrm{gpm}$ to $245 \mathrm{gpm}$ at $140^{\circ} \mathrm{F}$. The transmission pipeline for either of these cases will be necessary only if the heat load is separated from the well site or the heat pump. This pipeline must be capable of transporting the fluid without losing significant quantities of heat. At temperatures below $100^{\circ} \mathrm{F}$, the use of an insulated pipe is not warranted. If the $140^{\circ} \mathrm{F}$ output fluid from the heat pump is to be transported distances greater than one-haif mile, an insulated pipe must be considered.

The relatively low temperature requi rements of $140^{\circ} \mathrm{F}$, low pressure needs, and expected high water quality all combine to make nearly any piping material suitable for this use. The use of a concrete asbestos or fiberglass pipe are both suggested piping materials due to use in similartype applications. The slightly lower cost for the concrete asbestos pipe make it the recommended product. The pressure loss, temperature loss, and pricing, presented later, are all based on the use of concrete asbestos pipe.

For transporting the expected water flows of 150 or $300 \mathrm{gpm}$, a 3 -inch, 4-inch, or 6-inch pipe could be used dependent on transmission distance. Table 4 shows the expected pressure loss for various pipe sizes and flows through a concrete asbestos pipeline. Table 5 shows the corresponding expected temperature losses with and without insulation. As seen from Table 5, the use of insulated pipe greatly reduces the temperature loss. However, unless the pipeline is greater than approximately one-half mile in length, the use of the costly insulated pipe is not recommended. The pipelines will require burial at depths of 4-1/2 feet in order to get. below frost line. 


\section{TABLE 4. PRESSURE LOSS PER 1000 FEET OF A CONCRETE ASBESTOS PRODUCT}

\begin{tabular}{ccc}
$\begin{array}{c}\text { Pipe Size } \\
\text { (in.) }\end{array}$ & $\begin{array}{c}\text { Flow } \\
\text { (gpm) }\end{array}$ & $\begin{array}{c}\text { Pressure Loss } \\
\text { (psi) }\end{array}$ \\
\cline { 1 - 3 } 3 & 150 & 22.0 \\
4 & 150 & 5.3 \\
& 250 & 13.5 \\
& 300 & 18.9 \\
6 & 150 & 0.8 \\
& 250 & 2.1 \\
& 300 & 3.0
\end{tabular}

TABLE 5. TEMPERATURE LOSS IN ${ }^{\circ} \mathrm{F}$ PER 1000 FEET OF CONCRETE PIPE

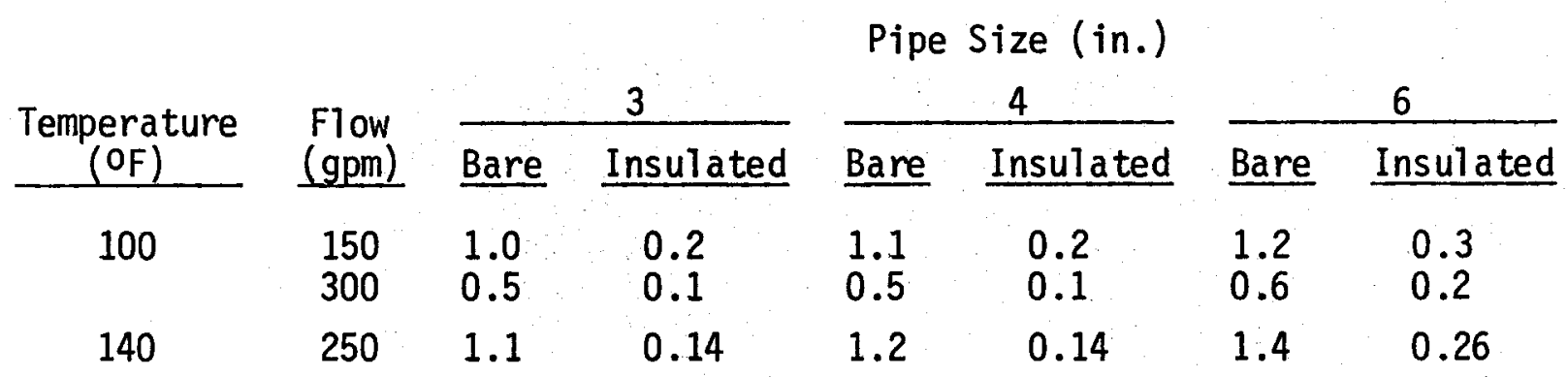

Pump

The pumps designed to transport the fluid through the pipeline range in size dependent on whether the geothermal fluid or warmed water from the heat pump is finally selected. Two pumps have been sized based on the two most probable design limitations, namely geothermal flows of either 150 or 300 gpm to be pumped up to one-half mile. For the larger flow, a 10-hp motor witl be required and a 5-hp motor for the lesser flow.

Design

Two specific design cases have been evaluated, both of which entail the use of heat pumps. The first involves the siting of both the heat pump and heat load adjacent to the well. The second design option is to have the heat pump at the well site and the heat load located one-half mile away. The reason for specifically evaluating the heat pump case and 
not direct-use application was the suggestion by Park Funding that a heat load could be more easily found for the $140^{\circ} \mathrm{F}$ heat source available only from the heat pump. The costs and payback periods presented in the next section are 211 based on the assumption that the full output from the heat pumps will be used for the six coolest months of the year. For four of these six months, the heat pump will deliver 3 million Btu/hr; in the other two months, 2,700,000 Btu/hr will be delivered. During the six warmer months of the year, the heat pump will not be in operation.

The following table is presented as a reference to determine the design heat load for buildings which may be located near the heat source. Since this development is still in early stages of planning, it is possible to locate the heat users near the heat supply. The $99 \%$ design temperature for the Castlerock region is $-3^{\circ} \mathrm{F}$.

TABLE 6. DESIGN HEAT LOADS FOR AVERAGE BUILDINGS

\begin{tabular}{ll}
\multicolumn{1}{c}{ Building } & Design Heat Load \\
\cline { 3 - 3 } School & $\frac{1}{10} 3 \times 10^{6} \mathrm{Btu} / \mathrm{hr}$ \\
Homes & $75,000 \mathrm{Btu} / \mathrm{hr}$ \\
Apartments/townhouses & $50,000 \mathrm{Btu} / \mathrm{hr}$ \\
Retail space & $30 \mathrm{Btu} / \mathrm{ft}^{2}-\mathrm{hr}$ \\
Office space & $25 \mathrm{Btu} / \mathrm{ft}^{2}-\mathrm{hr}$
\end{tabular}

As mentioned at the beginning of this report, the geothermal fluid will eventualiy be used for drinking water purposes. Figure 2 illustrates the path that the geothermal fluid would follow from the well to the final user. The warm water will pass through the heat pump where heat will be extracted. From the heat pump, the water will be piped to the treatment facility. The water will then be treated for domestic supply and sent to storage for use as needed.

An interesting possibility to augment the geothermal heat pump is to combine its use with solar energy. This could prove necessary to help balance the water supply demands and heating demands. We do not have complete information on the water usage; however, it may occur that the water required for heating needs exceeds that of the demand for domestic water. In this event, a solar-assist option could be used. Figure 3 illustrates this approach. During the daylight hours, solar energy could provide the heat needed to operate the heat pump and the 


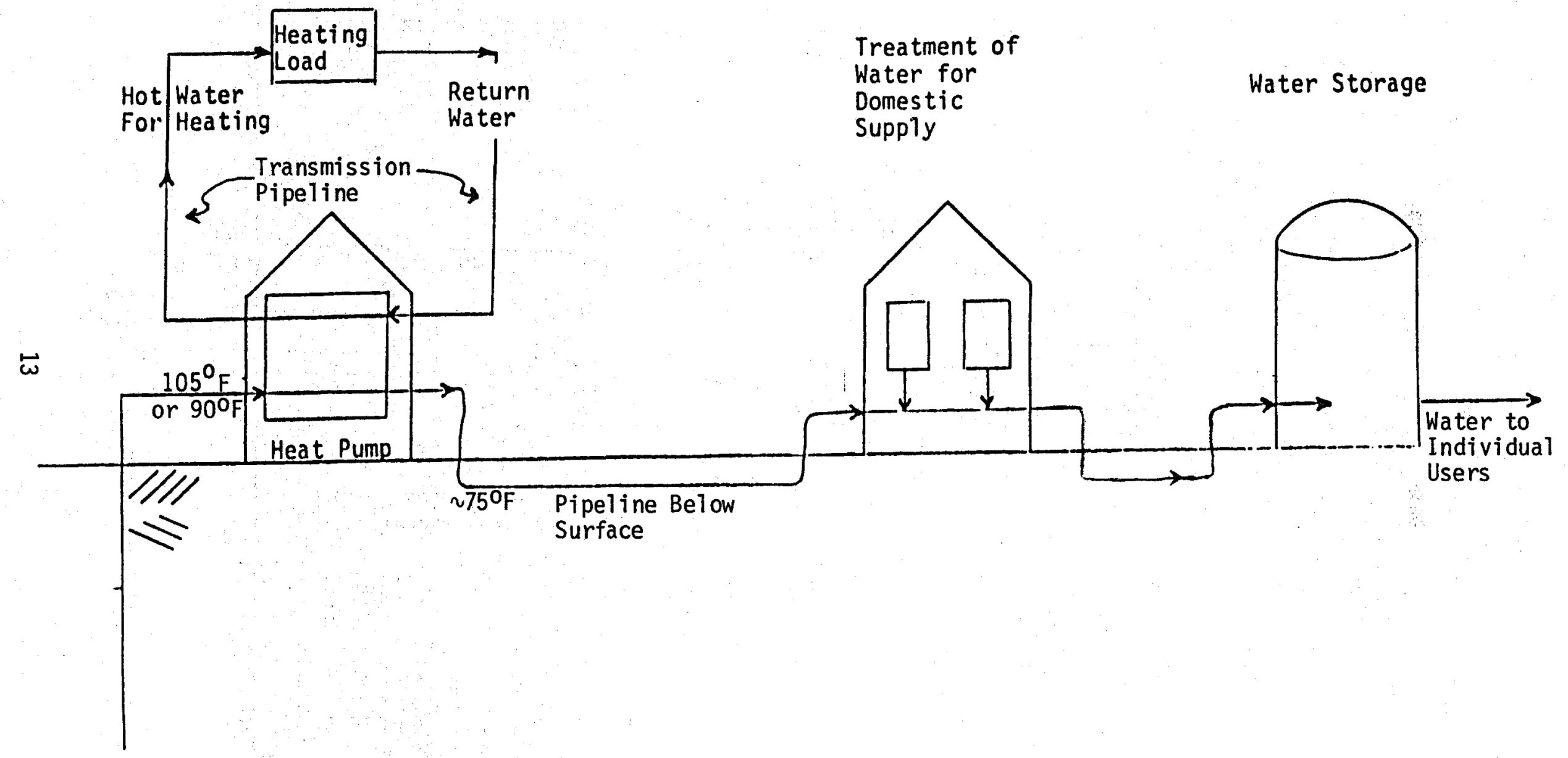

Figure 2. Schematic Diagram of Flow of Geothermal Fluid 


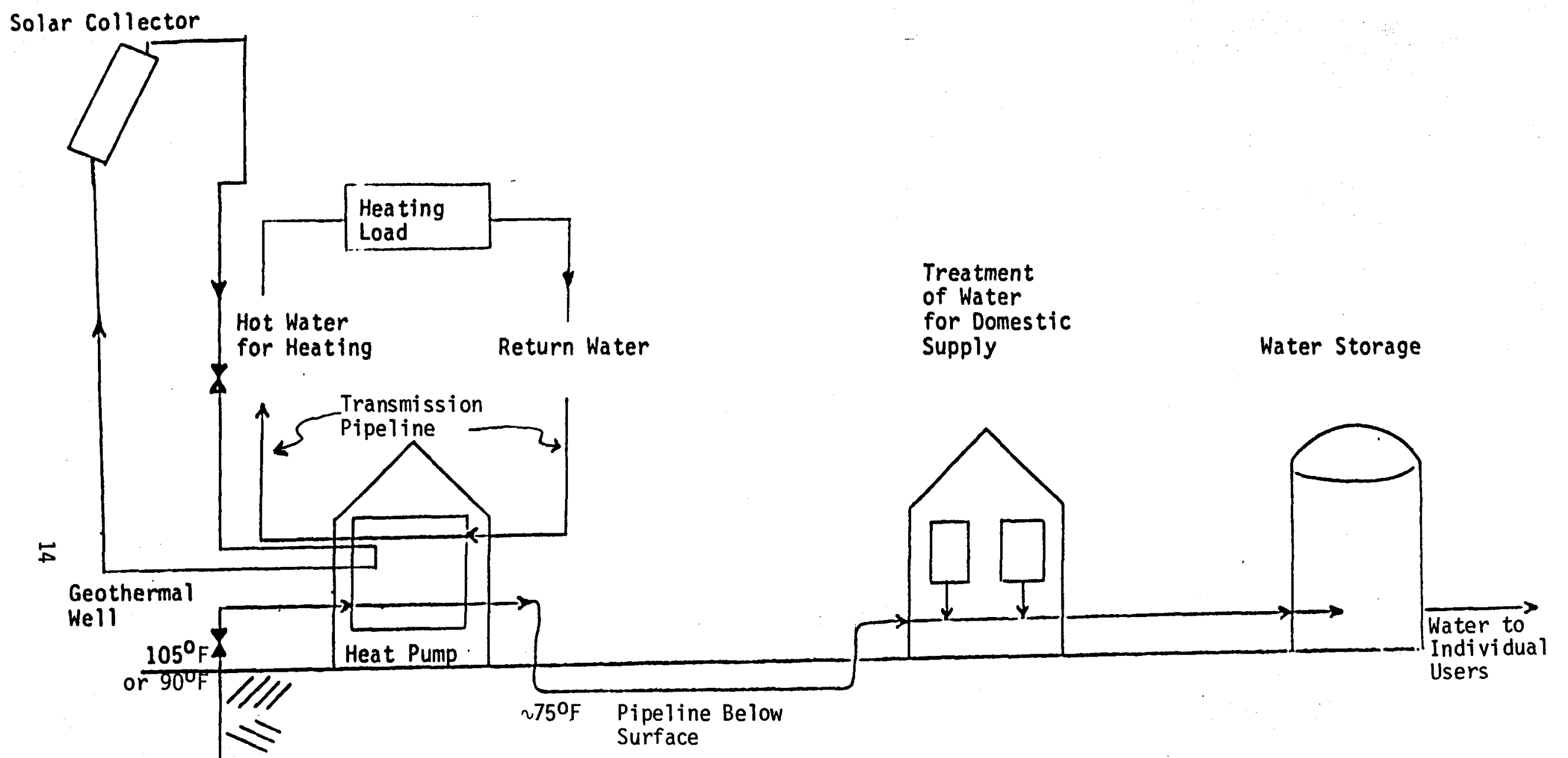

NOTE: Geothermal well provides heat pump requirements in evenings and overcast days. Solar collector provides heating during avallable daylight hours.

Figure 3. Schematic of Solar Assisted Geothermal Heat Pump 
wells would not be operational. At this time, water for domestic purposes would be removed from storage. During evening hours and overcast days, the wells would provide the water needed to operate the heat pumps. At these times, water from the wells would be produced for storage or use as needed. 


\section{ECONOMIC CONSIDERATIONS}

In this section, the capital and operating costs are presented based on the two design cases. Cost comparisons with other fuels are presented, as are simple payback calculations. A brief discussion of available tax incentives is given at the end of this section. At the request of Park Funding Corporation, the cost for wells and operation of the well pumps are not considered in this economic evaluation.

CAPITAL COSTS

There are three major equipment items associated with the use of the geothermal resource. These capital items are the heat pump, piping, and the circulating pump. The estimated purchase cost of the heat pump is $\$ 68,400$, with installation estimated at about $\$ 5000$. Both of these cost estimates were obtained from a representative of the manufacturer. The installation and purchase cost of $\$ 73,400$ for the heat pump is about three times the cost of a conventional gas-fired boiler.

The cost for the piping needed to transport the fluid can be estimated using the costs below:

\begin{tabular}{|c|c|}
\hline $\begin{array}{c}\text { Pipe Size } \\
\text { (in.) }\end{array}$ & $\begin{array}{c}\text { Cost } \\
\text { (per } f t)\end{array}$ \\
\hline $\begin{array}{l}3 \\
4 \\
6\end{array}$ & $\begin{array}{l}\$ 2.40 \\
\$ 3.80 \\
\$ 4.20\end{array}$ \\
\hline
\end{tabular}

For the design case where the heat pump is located at the well site and the heat load is removed by one-half mile, a 4-inch pipe will be needed. One pipe is needed to transport the warmed fluid to the heat load and another to return the cooled water to the heat pump. The cost for installing the two pipes in a common trench is estimated at $\$ 9 / \mathrm{ft}$. For the design case where both the heat pump and load are at the well site, the piping costs are estimated at $\$ 2000$ for the piping manifold. The total piping costs are included in Table 7. The figures presented in Table 7 include all installation costs. 
TABLE 7. TOTAL CAPITAL COSTS

\begin{tabular}{|c|c|c|c|c|}
\hline $\begin{array}{l}\text { Heat } \\
\text { Pump }\end{array}$ & Piping & $\begin{array}{l}\text { Circulating } \\
\text { Pump }\end{array}$ & Total & $\begin{array}{l}\text { Total Incremental } \\
\text { Capital Cost Com- } \\
\text { pared to Gas } \\
\text { System }\end{array}$ \\
\hline
\end{tabular}

Design Case 1

Separated heat load and heat pump

$\$ 73,400 \quad \$ 43,800 \quad \$ 7,000 \quad \$ 124,200 \quad \$ 99,200$

Design Case 2

Heat pump and heat

load located together at well

site

$\$ 73,400 \quad \$ 2,000 \quad \$ 5,000 \$ 80,400 \quad \$ 55,400$

The cost for the circulating pumps presented in Table 7 were estimated using the following design specifications.

\begin{tabular}{|c|c|c|c|}
\hline & $\begin{array}{c}\text { Flow } \\
\text { (gpm) }\end{array}$ & $\begin{array}{l}\text { Head } \\
(\mathrm{ft})\end{array}$ & $\begin{array}{r}\text { Power } \\
\text { (hp) }\end{array}$ \\
\hline Design Case 1 & 300 & 230 & 10 \\
\hline Design Case 2 & 300 & 40 & 5 \\
\hline
\end{tabular}

Operating Costs

The annual operating costs for the geothermal system consist of the electrical energy needs to operate the heat pump and circulating pump. The current electrical charge in the development area is $\$ 0.063 / \mathrm{kWh}$. With this rate, the annual operating costs are as follows:

$\begin{array}{lr}\text { Heat pump } & \$ 54,700 \\ \text { Circulating pump } & \$ 1,025 \\ 5 \mathrm{hp} & \$ 2,050 \\ 10 \mathrm{hp} & \$ 20\end{array}$

These values are based on the assumption that the heat pump will operate for six months at varying rates of output per year. Maintenance requests for the heat pump system were assumed equal to comparative gas systems.

\section{Annual Fuel Displaced}

Natural gas is the available heating source in the area. The effective price of natural gas assuming a furnace efficiency of $75 \%$ is 
$\$ 5.77 /$ million Btu exclusive of gas system capital cost requirements and their financing. The total amount of heat to be replaced during the sixmonth heat pump utilization period is $12,500 \times 10^{6} \mathrm{Btu}$ 's. This value assumes the entire heat load will be used. Based on these figures, the annual cost in natural gas would be $\$ 72,125$. This would result in a net savings in annual operating costs of $\$ 15,375$ and $\$ 16,400$ for Design Case 1 and Design Case 2, respectively.

\section{Payback}

A simple payback calculation was performed by dividing the annual operating cost saving into the total incremental capital costs and exclusive of financing costs and escalating fuel costs. These calculation results are shown in Table 8.

TABLE 8. SIMPLE PAYBACK CALCULATION

\begin{tabular}{cc} 
& $\begin{array}{c}\text { Payback Period } \\
\text { (yrs) }\end{array}$ \\
\cline { 2 - 2 } Design Case 1 & 6.45 \\
Design Case 2 & 3.4
\end{tabular}

The cost for wells and the cost to pump the wells have been specifically excluded at the request of Park Funding. This is due in part to the fact that the wells are drilled and will be pumped for domestic water supply, regardless of any utilization of the groundwater heat. The impact of the available tax incentives has also been excluded. This approach has been taken since the applicability of these regulations is not well defined for this particular situation due to previous water development plans and the low temperature resource $\left(<50^{\circ} \mathrm{C}\right)$. If the $\operatorname{tax}$ incentives can be applied, the economics of the project might be further improved.

The delivered energy cost for the geothermally assisted option over a 20-year period is dependent on capital and operating costs, equity investment, financing rates, demanded project rate of return, depreciation, tax credits, tax rates, and inflation rates. The delivered cost of energy for the two design cases presented were calculated for the case of $100 \%$ 
equity financing, a project rate of return of $15 \%$, and for $0 \%$ inflation rates of electricity and gas costs. Results are presented in Table 9.

TABLE 9. 20-YEAR ENERGY COSTS

\begin{tabular}{|c|c|c|}
\hline & $\begin{array}{l}\text { Del ivered } \\
\text { Energy } \\
\text { Cost } \\
\end{array}$ & Payback \\
\hline $0 \%$ Inflation & $\left(\$ / 10^{6} \mathrm{Btu}\right)$ & \\
\hline Design Case 1 & $\$ 6.42$ & 5.6 years \\
\hline Design Case 2 & $\$ 5.64$ & 4.7 years \\
\hline Natural Gas Case* & $\$ 6.70$ & \\
\hline
\end{tabular}

If equity financing is decreased, delivered energy costs rise due to the interest expense incurred for the borrowed money. For example, if $100 \%$ financing is assumed, as compared to total equity financing, the delivered energy cost for Design Case 1 rises to $\$ 7.68 / \mathrm{mill}$ ion Btu.

If inflation of gas and electricity fuel costs are factored in, the delivered energy cost again rises since the principal operating costs are for electrical requirements to drive the pumps and the compressor in the heat pump system. In this instance, the geothermaliy assisted heat pump option would be more attractive than the natural gas option whose total annual operating cost is higher--essentially the delivered price of the gas product. If $7.5 \%$ inflation rates are assumed in delivered energy costs, equivalent 1982 energy prices for the geothermally assisted Design Case 2 and the natural gas case are $\$ 5.24$ per million Btu and $\$ 6.56$ per million Btu, respectively.

For zero inflation rates, comparative cumulative 20-year energy costs are presented in Table 10. A 20-year savings of $\$ 265,000$ is indicated. 
TABLE 10. COMPARATIVE 20-YEAR ENERGY COSTS ZERO INFLATION RATES

Geothermally Assisted

System

(Design Case 2)

Natural Gas

$\$ 1.41$ million

$\$ 1.675$ million

Finally, it is noteworthy that additional efforts should be made to find uses for the final $75^{\circ} \mathrm{F}$ cooled water stream. If a cost-effective use could be forthcoming, the system's economics could be further improved. 
TAX INCENTIVES FOR GEOTHERMAL DEVELOPMENT

The principal legislation and regulations governing energy credits and incentives available from the federal government and the State of colorado are summarized on the following pages. These regulations apply to the following areas:

- Energy Tax Credit--an investment tax credit that may be applicable in addition to the existing investment tax credit

- Intangible Drilling Cost Deductions

- Depletion Allowance

For clarity of organization, these are discussed individually. The following summaries represent our best understanding of the impact of the tax law made available to us through review of pertinent documents and communication with other members of the geothermal community. Tax 1 aw and the regulations that provide guidance for compliance are detailed, complex subjects. We suggest that these enclosures be used as the bas is for additional discussions with your tax consultant. 
Currently, the federal government allows an investment tax credit of $10 \%$. Alternative Energy Tax Credit provides for an additional 15\% investment tax credit above the regular investment credit. It may offset $100 \%$ of tax liability remaining after applying the regular credit. For geothermal, the credit expires after 1985.

The IRS Final Regulations, 26 CFR Part 1, Investment Credit for Energy Property, provide guidance to compliance with the Energy Tax Act of 1978. See Federal Register v. 46, no. 15, January 23, 1981. The crude-0il Windfal1 Profit Tax Act, passed March 1, 1980, expanded the scope and extended the timetable for gaining these credits.

\section{Definitions and Eligibility Criteria}

Al ternative energy property includes:

- Equipment which uses an alternate substance as a fuel.

- Pollution control equipment eligible if installed in connection with eligible al ternative energy property.

- Equipment used to produce, distribute, or use energy derived from a geothermal deposit. Al though the wellhead temperature cited is $>50^{\circ} \mathrm{C}\left(122^{\circ} \mathrm{F}\right)$, this is subject to interpretation.

1. Must be specifically adapted to use geothermal energy.

2. Must be used exclusively with energy derived from a geothermal deposit.

a. Production equipment (to bring energy to surface): wellhead and downhole equipment; screening or slotted liners, tubing and downhole pumps; reinjection well property.

b. Distribution equipment--transport to site of ul timate use; components of a heating system, e.g. pipes and ductwork within a building.

c. Exclusive: not eligible are:

--A backup system using other water

--Addition of heat before circulation (geothermal water not hot enough); nei ther boiler nor circulating system is geothermal equipment in that situation 
Sec. 402, Energy Tax Act of 1978

1. OPTION TO DEDUCT INTANGIBLE DRILLING COSTS

For tax purposes, the costs of drilling and completing a geothermal well are divided into two classes: intangible drilling costs and capital costs. Capital costs must be recovered through depreciation.

Intangible drilling costs are those incurred which, in themselves, have no salvage value and which are "incident to and necessary for the drilling of wells ..." Such expenditures expressly include "wages, fuel, repairs, hauling, supplies, etc." that are used: (1) in the drilling and cleaning of wells; (2) in such clearing of ground, draining, road making, surveying, and geological and hydrological evaluations as are necessary in preparation for the drilling of the wells; and (3) in the construction of such derricks, tanks, pipelines, and other physical structures as are necessary for the drilling of wells and the preparation of wells for production.

They may be expensed (deducted as expenses) in the year in which they were incurred or they may be capitalized and deducted over a certain period of time as depreciation. Al lowing a taxpayer to expense (deduct) all the intangibles in the year in which they were incurred gives the taxpayer an "accelerated depreciation."

The taxpayer must make his election to expense or to capitalize intangibles in the first taxable year in which he incurs such costs. Once having done so, the taxpayer must treat such expenditures on all geothermal properties in the same manner for all future years. However, if the taxpayer elects to capitalize his intangibles, he is granted a second election to capitalize or to expense the portion of intangibles attributable to dry or nonproductive wells.

\section{PREFERENCE INCOME--MINIMUM TAX}

Some types of income are given preferential treatment by special provisions of the tax law. A minimum tax applies to a number of items that are considered to be of a tax-preference nature. These types of 
income include capital gains, stock options and income offset by depletion, amortization and intangible drilling costs. The tax is computed by totaling all the items of tax preference, then reducing this amount by the greater of $\$ 10,000$ or one-half a taxpayer's regular income tax after reduction by credits. A flat $15 \%$ rate is then applied against the balance. Preference income is applied differently to individual taxpayers as compared to corporations.

If certain taxpayers have "excess intangible drilling costs" that exceed net geothermal income, he will have preference income subject to the minimum tax. Intangible drilling costs are considered to be excessive when the intangible drilling and development costs of a geothermal well al lowable for the tax year is greater than the sum of: (1) the amount allowable if the costs had been capitalized and straight-line recovery of intangibles had been used; and (2) the net income for the tax year from the geothermal property.

Straight-line recovery means the ratable amortization of such intangibles over the 120 -month period beginning with the month in which production from the well begins (or, if elected, any method which would be permitted for purposes of determining cost depletion). Net income from geothermal properties means the gross income from all such property reduced by any deductions al locable to the properties, except intangible drilling and development costs in excess of straight-line recovery.

This preference does not apply to taxpayers who elect to capitalize their intangibles by straight-line recovery; nor does it apply to nonproductive wells. In effect, what this provision does is to lessen the benefit of the option to expense intangible drilling costs. Few taxpayers now have geothermal income and if they choose to expense intangibles, they will have preference income; i.e., the amount they deduct by expensing intangibles will be greater than the sum of intangibles capitalized and net geothermal income. This preference tax on intangible drilling deductions is not applicable, however, to corporations. 


\section{DEPLETION ALLOWANCE}

The owner of an economic interest in a geothermal resource may recover his cost through federal tax deductions for depletion over the economic life of the property.

The IRS provides two methods of computing a depletion allowance: cost depletion and percentage depletion. Cost depletion provides for a deduction for the taxpayer's basis (cost) in the property in relation to the production and sale of minerals from the property. On the other hand, percentage depletion is a statutory concept that provides for a deduction of specified percentages of the gross income from the property. The deduction, however, can not exceed $50 \%$ of the net income from the property. A taxpayer is required to compute depletion both ways and to claim the larger of the two amounts.

A depletion allowance reduces the taxpayer's bas is in a property but the total amount taken as a depletion allowance is not restricted to the taxpayer's basis. Even though cost depletion will be zero after the taxpayer's initial basis has been recovered (for example, $T$ deducts $\$ 5000$ per year for five years for a total of $\$ 25,000$-- the amount of his original investment), the taxpayer may continue to claim percentage depletion based on income from the property.

Section 403 of the 1978 Energy Tax Act grants percentage depletion on income from geothermal deposits. The rate through 1980 is $22 \%$. It decreases by $2 \%$ yearly until 1983 and thereafter the rate is $15 \%$; thus, the 1981 percentage is $20 \%$.

There is some question about the availability of depletion on minerals which are consumed by the producer of such minerals. One way for the corporate taxpayer to avoid the problem is to conduct its exploration and development activities through a whol ly owned subsidiary. 


\section{COLORADO ENERGY TAX CREDIT}

A commercial or industrial taxpayer can subtract from the state income tax bill 10\% of the cost of any "energy property" provided the expenditures are made during taxable years 1981 through 1986.

The state credit includes all the energy properties defined under the 1978 Federal Energy Tax Act, but excludes pollution control equipment. Alternative energy properties include equipment to generate heat from a geothermal deposit. Heat pumps are specifically excluded.

The state's investment tax credit applies to expenditures up to $\$ 1.25$ million for the 1981 taxable year, $\$ 1.75$ million for the 1982 taxable year, and $\$ 2.25$ million for the 1983, 1984, 1985, and 1986 taxable years. The credits can be carried forward five years if they exceed tax liability. 


\section{SUMMARY}

Commercial heat pumps are available to utilize the geothermal resource at the development. The initial installation costs for the required heat pump are higher than for a conventional gas system. Lower annual operating costs for the heat pump system permit recovery of the initial capital expense dependent on the financing requirements applicable to the invested capital. With the resource availability at the Castle Oaks development and current energy costs, the simple payback period for the heat pump is less than seven years as compared to a conventional gas system. This payback period is based on full utilization of the heat pump for only six months of the year. No tax incentives were considered in the payback calculations. The 20-year delivered energy costs for the geothermally assisted options range from $\$ 5.64$ to $\$ 6.42$ per million Btu for zero inflation rates. This compares to natural gas costs of $\$ 6.70$ per million Btu. 


\section{BIBLIOGRAPHY}

Garing, K. L., and F. R. Connor. 1981. Groundwater Heat Pumps in Colorado, An Efficient and Cost-effective Way to Heat and Cool Your Home. Special Publication 18, Colorado Geological Survey, Denver, Colorado. $36 \mathrm{pp}$.

Hederman, W. F., Jr., and L. A. Cohen. 1981. Economic Assessment of Geothermal Direct Heat Technology, A Review of Five DOE Demonstration Projects. DOE/ID/12099-1, U.S. Department of Energy, Idaho Operations Office. $83 \mathrm{pp}$.

Johns-Manville, 1977. Thermal Tables for Underground Heating and Cooling Systems. Denver, Colorado. $55 \mathrm{pp}$.

U.S. Department of Energy. 1981. Geotherma1 Direct Heat Applications, Program Summary, Semi-annual Review Meeting, Boise, Idaho. 2nd Printing. $196 \mathrm{pp}$. 